\title{
Using drug scheduling to manage adverse events associated with hedgehog pathway inhibitors for basal cell carcinoma
}

\author{
John T. Lear ${ }^{1}$, Reinhard Dummer ${ }^{2,3}$ and Alexander Guminski ${ }^{4,5}$ \\ ${ }^{1}$ Manchester Academic Health Science Centre, University of Manchester, Manchester, UK \\ ${ }^{2}$ Department of Dermatology, University Hospital, University of Zurich, Zurich, Switzerland \\ ${ }^{3}$ Skin Cancer Center, University Hospital, University of Zurich, Zurich, Switzerland \\ ${ }^{4}$ Department of Medical Oncology, Royal North Shore Hospital, St Leonards, Australia \\ ${ }^{5}$ Faculty of Medicine, Sydney Medical School, The University of Sydney, Sydney, Australia \\ Correspondence to: John T. Lear, email: john.lear@srft.nhs.uk \\ Keywords: adverse events; basal cell carcinoma; sonidegib; hedgehog inhibitor; drug scheduling \\ Received: October 08, $2021 \quad$ Accepted: November 10,2021 Published: December 21, 2021
}

Copyright: (๑) 2021 Lear et al. This is an open access article distributed under the terms of the Creative Commons Attribution License (CC BY 3.0), which permits unrestricted use, distribution, and reproduction in any medium, provided the original author and source are credited.

\section{ABSTRACT}

Basal cell carcinoma (BCC) is the most common malignancy and form of skin cancer worldwide; advanced BCC, either as locally advanced BCC (IaBCC) or metastatic BCC ( $\mathrm{mBCC})$, can cause substantial tissue invasion and morbidity. Until the recent availability of the hedgehog pathway inhibitors (HHIs) sonidegib and vismodegib, treatment options for advanced BCC were limited. These agents demonstrate efficacy in patients with laBCC and $\mathrm{mBCC}$; however, the adverse events (AEs) associated with these agents can lead to treatment interruption or discontinuation and reduced quality of life, all of which significantly impact long-term adherence to therapy, which might affect clinical outcome. Given that most AEs are class-related effects, switching HHIs does not appear to lead to a significantly different AE profile, underscoring the importance of maintaining patients on their first HHI. Interrupting treatment of sonidegib and vismodegib does not appear to undermine the efficacy of these agents and is therefore a practical option to manage AEs in order to maintain continued treatment and disease control.

\section{INTRODUCTION}

Basal cell carcinoma (BCC) is the most common malignancy and form of skin cancer worldwide $[1,2]$. BCC accounts for most $(\sim 80 \%)$ of the approximately 3.5 million global annual diagnoses of nonmelanoma skin cancer [1]. BCC infrequently results in death or metastasis; however, advanced $\mathrm{BCC}$, either as locally advanced $\mathrm{BCC}(\mathrm{laBCC})$ or metastatic $\mathrm{BCC}(\mathrm{mBCC})$, can cause substantial tissue invasion and morbidity $[2,3]$. Severe (advanced) BCC accounted for $<1 \%$ of all BCCs in almost 10,000 patients at 1 tertiary referral center [4]. Primary treatments for BCC include cryotherapy, curettage and electrodessication, surgical excision, Mohs micrographic surgery, and radiation therapy [5]. While these treatments are generally successful, treatment options for patients with advanced BCC are more limited. Moreover, since about $80 \%$ of BCCs appear on the head and neck [6], excision of locally advanced lesions in these areas can cause disfigurement and loss of function.
The hedgehog signaling pathway regulates normal cell development and proliferation and plays a key role in the development of BCC [1, 7-9]. In particular, most BCCs are associated with upregulation of the hedgehog signaling pathway due to mutations in the human homologue of the Drosophila patched (PTCH1) gene or smoothened (SMO) protein $[1,7,9]$. Inhibition of the hedgehog signaling pathway is therefore a rational treatment option in patients with advanced BCC. Vismodegib (Erivedge ${ }^{\circledR}$; Genentech USA Inc.; South San Francisco, CA, USA) and sonidegib $\left(\mathrm{Odomzo}^{\circledR}\right.$; Sun Pharmaceutical Industries, Inc.; Cranbury, NJ, USA) are hedgehog pathway inhibitors (HHIs) that selectively target $S M O$. These drugs are approved by the Food and Drug Administration (FDA) and European Medicines Agency (EMA) for treatment of laBCC that has recurred following surgery or radiation therapy or those who are not candidates for surgery or radiation therapy; vismodegib has also been approved by the FDA and EMA for $\mathrm{mBCC}$, and both agents are approved for treatment of $\mathrm{mBCC}$ in Australia and Switzerland [10-13]. 
Table 1: Characteristics of vismodegib and sonidegib from pivotal trials used for approval $[10,11,22,32]$

\begin{tabular}{|c|c|c|}
\hline & Vismodegib (Erivedge) & Sonidegib (Odomzo) \\
\hline Pivotal trial for approval & ERIVANCE phase 2 trial & BOLT phase 2 trial \\
\hline Date of approval & $\begin{array}{l}\text { FDA: January } 2012 \\
\text { EMA: July } 2013\end{array}$ & $\begin{array}{l}\text { FDA: July } 2015 \\
\text { EMA: August } 2015\end{array}$ \\
\hline Dosage & $150 \mathrm{mg} /$ day oral capsule & $200 \mathrm{mg} /$ day oral capsule \\
\hline Pharmacokinetics & $\begin{array}{l}\text { Oral bioavailability, } 32 \% \text { (single } \\
\text { dose); } 7 \% \text { (multiple dose) } \\
\text { Plasma protein binding, }>97 \% \\
\text { Volume of distribution, } 16.4-26.6 \mathrm{~L} \\
\text { Elimination half-life, } 12 \text { days (single } \\
\text { dose); } 4 \text { days (multiple dose) }\end{array}$ & $\begin{array}{l}\text { Oral bioavailability, }<10 \% \\
\text { Plasma protein binding, }>99 \% \\
\text { Volume of distribution, }>9000 \mathrm{~L} \\
\text { Elimination half-life, } 28 \text { days }\end{array}$ \\
\hline Overall response rate & $\begin{array}{l}39 \text { months (investigator reported) [35] } \\
\text { laBCC, } 60.3 \% \\
\text { mBCC, } 48.5 \%\end{array}$ & $\begin{array}{l}42 \text { months (central review) [37] } \\
\text { laBCC, } 56 \% \\
\text { mBCC, } 8 \%\end{array}$ \\
\hline Adverse events & $\begin{array}{l}\text { Muscle spasms, alopecia, dysgeusia, } \\
\text { weight loss, fatigue, nausea, diarrhea, } \\
\text { constipation, decreased appetite, } \\
\text { arthralgias }\end{array}$ & $\begin{array}{l}\text { Muscle spasms, alopecia, dysgeusia, fatigue, } \\
\text { nausea, musculoskeletal pain, diarrhea, } \\
\text { decreased weight, decreased appetite, } \\
\text { myalgia }\end{array}$ \\
\hline
\end{tabular}

Abbreviations: EMA: European Medicines Agency; FDA: Food and Drug Administration.

While the HHIs are important treatment advances for patients with advanced BCC, a population with previously limited treatment options, the safety profile of these agents significantly impacts long-term adherence to therapy [14]. Adverse events (AEs) associated with HHIs can lead to treatment interruption or discontinuation and reduced quality of life, all of which might affect clinical outcome. Given that most AEs are class related, switching HHIs does not appear to lead to a significantly different AE profile [14]. This underscores the importance of maintaining patients on their first HHI. This article reviews the pivotal clinical trials in advanced $\mathrm{BCC}$ of vismodegib and sonidegib and provides clinical strategies for managing AEs to maximize benefit from therapy.

\section{Hedgehog pathway in $\mathrm{BCC}$}

The hedgehog signaling pathway is usually silenced in most normal adult tissues; however, it plays a pivotal role in repair of damaged tissues, promotion of stem cell proliferation, and regulation of maintenance of tissues including muscle, hair, taste buds, and the reproductive system [15-18]. The pathway can be stimulated by 3 hedgehog ligands, including Sonic hedgehog, Indian hedgehog, and Desert hedgehog; Sonic hedgehog is the most widely expressed in adult tissues and the most potent of these ligands $[16,19]$. The primary receptor for these ligands is PTCH1 [9]. PTCH1 inhibits SMO in the absence of the hedgehog ligands, whereas ligand binding relieves the inhibitory effects of PTCH1 on SMO. SMO suppression is crucial for normal cell regulation and proliferation; activation of SMO signaling leads to activation of the glioma-associated oncogene (GLI) transcription factors GLI1, GLI2, and GLI3; GLI1 activates genes associated with tumorigenesis (eg, cyclin-D1, $M Y C, B C L 2$ ) and angiogenesis [16].

In $\mathrm{BCC}$, the hedgehog signaling pathway is typically activated by mutations that lead to $P T C H 1$ gene dysfunction, which is almost universally observed in patients with BCC nevus syndrome and in most patients (80\%-90\%) with sporadic BCC tumors, whereas $10 \%$ of patients have $S M O$ gene mutations $[14,18]$. Both mutation types lead to constitutive SMO signaling and BCC development [18]. Activation of the Sonic hedgehog signaling pathway (by the deactivating mutation of $\mathrm{PTCH}$ or activating mutations of SMO) is therefore key to developing BCC.

\section{Hedgehog pathway inhibitors in BCC}

The discovery of the importance of hedgehog pathway signaling in oncogenesis led to the development of the HHIs [20]. As noted above, there are currently 2 hedgehog inhibitors approved for use in advanced BCC: vismodegib and sonidegib. This section overviews the pharmacology and clinical efficacy and safety of these 2 orally available small-molecule drugs in advanced BCC (Table 1).

\section{Pharmacodynamics}

Ligand-independent pathway activation by SMO is one of the mechanisms believed to be involved in tumorigenesis [21]. Sonidegib and vismodegib are selective HHIs; they bind to and inhibit SMO, a 
transmembrane protein involved in hedgehog signal transduction $[10,22]$. SMO inhibition results in transcription factors GLI1 and GLI2 remaining inactive, thus preventing expression of tumor-mediating genes within the hedgehog pathway [23].

In a phase I study in 33 patients with $\mathrm{mBCC}$ or laBCC, tumor GLI1 was overexpressed as compared with normal skin controls; skin biopsies showed that GLII expression was down-modulated more than 2-fold in 10 (77\%) of 13 patients following treatment with vismodegib [24]. Vismodegib showed antitumor activity, with response seen in $18(55 \%)$ of 33 patients; of the remaining 15 patients, 11 had stable disease and 4 had progressive disease. GLI1 down-modulation did not correlate with vismodegib levels in individual patients.

In vitro studies and animal models demonstrate the targeted inhibition of hedgehog signaling and the antitumor activity of sonidegib; oral administration of sonidegib in mouse models resulted in complete suppression of GLI1 expression and tumor regression $[25,26]$. Sonidegib showed dose- and exposure-dependent inhibition of GLII in BCC tumor and normal skin biopsies [27]. The observed tumor responses were associated with evidence of hedgehog pathway activation. In the phase 2 Basal Cell Carcinoma Outcomes with LDE225 (sonidegib) Treatment (BOLT) study in patients with laBCC who had valid biomarker samples, the median percentage of reduction in GLI1 expression levels associated with sonidegib treatment (200 mg/day) was $>90 \%$ at weeks 9 and 17 [28]. Moreover, the greatest reductions from baseline were observed in patients who had disease control, consistent with hedgehog pathway inhibition.

\section{Pharmacokinetics}

Vismodegib has a mean absolute bioavailability of $32 \%$ following a single dose, and absorption was saturable, as evidenced by a considerably lower bioavailability $(\sim 7 \%)$ after continuous once-daily dosing [29]. The drug exhibits nonlinearity with respect to dose, as increasing the dosage from $150 \mathrm{mg}$ once daily (the approved dose) to $270 \mathrm{mg}$ or $540 \mathrm{mg}$ once daily did not result in higher steady-state plasma concentrations; nonlinearity with respect to time was also observed, as steady-state plasma concentrations were achieved earlier than expected (typically within 7-14 days) and were lower than expected, based on single-dose pharmacokinetics [29-31].

Vismodegib is highly bound to plasma proteins ( $>99 \%$ ), has a low volume of distribution (16-27 L), and is primarily eliminated by hepatic metabolism and biliary/intestinal excretion of unchanged drug $(82 \%$ recovered in the feces and 4\% recovered in urine) [22]. CYP2C9 appears to contribute in part to vismodegib metabolism [32]. The estimated terminal elimination half-life of vismodegib is about 12 days following a single dose and 4 days after continuous once-daily dosing [22], reflecting the increased clearance seen with repeated administration [33].

Sonidegib has a bioavailability of less than $10 \%$ following oral administration, but absorption increased 7 to 8 fold following administration with a high-fat meal [10]. The drug exhibits dose-proportional increases in maximum plasma concentrations over the dose range from 100 to $400 \mathrm{mg}$ but less-than-proportional increases above $400 \mathrm{mg}$ [11]. Steady-state drug concentrations are reached about 4 months after starting oral sonidegib [11]. The drug is highly bound ( $>97 \%$ ) to plasma proteins and has a high volume of distribution (>9000 L); steady-state sonidegib levels are 6 fold higher in skin than in plasma [11].

Sonidegib is metabolized in the liver by CYP3A4; the main circulating compound is unchanged sonidegib (36\%) and the circulating metabolites (45\%) [11]. Sonidegib and its metabolites are mainly eliminated by the hepatic route, with about $70 \%$ eliminated in the feces and $30 \%$ eliminated in the urine [10]. The elimination half-life of sonidegib is about 28 days [11].

\section{Treatment response in $\mathrm{BCC}$}

ERIVANCE is an international, nonrandomized, single-arm, 2-cohort, multicenter trial that assessed the efficacy of vismodegib $150 \mathrm{mg}$ daily in patients with laBCC and mBCC [34]. BOLT is an international, randomized, double-blind, multicenter trial of sonidegib $200 \mathrm{mg}$ or $800 \mathrm{mg}$ daily in patients with laBCC and mBCC [28]. ERIVANCE and BOLT both used objective response rate (ORR) by central review as the primary endpoint; ERIVANCE used conventional Response Evaluation Criteria in Solid Tumors (RECIST), while the more recent BOLT study used the more stringent modified RECIST (mRECIST) to assess BCC severity [28, 34]. Secondary efficacy endpoints included investigatorassessed best response, including complete response (CR), partial response (PR) and stable disease (SD), duration of response (DOR), progression-free survival (PFS), and overall survival (OS).

In ERIVANCE, 96 patients (63 with laBCC and 33 with $\mathrm{mBCC}$ ) were evaluated for efficacy; $61 \%$ of patients were men, and median age was 62 years [34]. At the initial 9-month follow-up primary analysis (all patients had potential to be followed $\geq 9$ months; the median duration of treatment was 10.2 months) [22]. ORRs in patients with laBCC were $42.9 \%(27 / 63)$ by independent review and $60.3 \%(38 / 63)$ by site investigator; ORRs for BCC mBCC were $30.3 \%(10 / 33)$ by independent review and $45.5 \%$ $(15 / 33)$ by site investigator [34]. At the 39-month followup, ORRs (reported by investigator review only) were similar to those at the initial follow-up $(60.3 \%(38 / 63)$ for laBCC and 48.5\% (16/33) for mBCC); 20, 18, and 15 patients in the laBCC group had complete responses, partial responses, or stable disease, respectively, and the corresponding numbers in the $\mathrm{mBCC}$ group were 0,16 , and 14, respectively (all per investigator review) [35]. 
Median duration of response per investigator review was 26.2 months in the laBCC group (38 responders) and 14.8 months in the mBCC group (16 responders) [35].

Other major clinical studies with vismodegib include the SafeTy Events in VIsmodEgib (STEVIE) study, a phase 2 , single-arm, open-label, multicenter study evaluating safety and efficacy of the drug (150 mg daily) in patients with advanced BCC (laBCC or $\mathrm{mBCC}$ ) in a setting representative of clinical practice [6] and MIKIE, a phase 2, randomized, double-blind, regimen-controlled, multicenter study evaluating the safety and efficacy of intermittent vismodegib doses (150 mg daily for 12 or 24 weeks, placebo for 8 weeks, then $150 \mathrm{mg}$ daily for 8 weeks) in patients with multiple BCCs [36]. In STEVIE, ORRs (investigator assessed) at week 73 were $68.5 \%$ in 1077 patients with laBCC and $36.9 \%$ in 84 patients with $\mathrm{mBCC}$; CR rates were $33.4 \%$ and $4.8 \%$, respectively [6]. In MIKIE, patients receiving the 12 -week regimen $(n=$ $116)$ achieved a $63 \%$ reduction in the number of BCCs and an $83 \%$ reduction in the size of BCCs; the corresponding values for the 24 -week regimen $(n=113)$ were $54 \%$ and $69 \%$, respectively [36].

BOLT enrolled 79 patients in the sonidegib 200 mg group (66 with laBCC and 13 with $\mathrm{mBCC}$ ) and 151 patients in the $800 \mathrm{mg}$ group (128 with laBCC and 23 with $\mathrm{mBCC})$; median age was approximately 66 years, and $63 \%$ of patients were men [28]. In the initial primary efficacy analysis (median follow-up of 13.9 months; central review), 36.4\% of patients (20/55) in the $200 \mathrm{mg}$ group $(42.9 \%(18 / 42)$ and $15.4 \%(2 / 13)$ in the laBCC and $\mathrm{mBCC}$ groups, respectively) and $33.6 \%(39 / 116)$ in the $800 \mathrm{mg}$ group $(37.6 \%(35 / 93)$ and $17.4 \%(4 / 23)$ in the laBCC and mBCC groups, respectively) achieved an objective response [28]. In the BOLT final analysis (42 months; central review), ORR was achieved in 56\% of patients with laBCC and $8 \%$ of patients with $\mathrm{mBCC}$ in the $200 \mathrm{mg}$ group and in $46 \%$ with laBCC and $17 \%$ with $\mathrm{mBCC}$ in the $800 \mathrm{mg}$ group [37]. In the sonidegib 200 $\mathrm{mg}$ group, median duration of response for responders per central review was 26.1 months in the laBCC group and 23.3 months in the $\mathrm{mBCC}$ group; in the $800 \mathrm{mg}$ group, median DOR was 24.0 months in the laBCC group and not estimable in the mBCC group [37].

\section{Adverse events}

AEs associated with HHIs are very common and can be a significant limiting factor for continuous treatment. The median durations of exposure in ERIVANCE and STEVIE were 13 months [35] and 9 months [6], respectively. All patients experienced an AE in ERIVANCE; 58 (56\%) experienced grade $\geq 3$ AEs, 9 (9\%) experienced serious treatment-related AEs, and 22 (21\%) discontinued due to AEs [35]. The most commonly reported AEs were muscle spasms in 74 patients (71\%), alopecia in 69 patients $(66 \%)$, and dysgeusia in 58 patients (56\%). In STEVIE, 1192 patients (98\%) experienced an
AE, 531 (45\%) experienced grade $\geq 3$ AEs, 289 (24\%) experienced serious AEs, and $380(31 \%)$ discontinued due to AEs [6]. Muscle spasms $(n=807 ; 66 \%)$, alopecia $(n=$ $747 ; 62 \%)$, and dysgeusia $(n=663 ; 55 \%)$ were commonly reported AEs in STEVIE.

In MIKIE, median durations of vismodegib exposure were 71.4 weeks in the 12 week group and 68.4 weeks in the 24 week group; 33 patients $(29 \%)$ and 40 patients $(35 \%)$, respectively, experienced grade $\geq 3$ AEs, and $6(5 \%)$ and $2(2 \%)$, respectively, experienced serious AEs related to treatment [36]. Discontinuations due to AEs were reported in 23 patients $(20 \%)$ and 30 patients $(27 \%)$, respectively, and the most common AEs (12- and 24-week groups, respectively) were muscle spasms (73\% and $83 \%)$, dysgeusia (66\% and 67\%), and alopecia (63\% and 65\%).

The safety and tolerability profiles of sonidegib were more favorable for the approved 200-mg dose than those for the $800-\mathrm{mg}$ dose. Median duration of exposure to sonidegib at the completion of BOLT was 11 months for the approved 200-mg dose and 6.6 months for the 800-mg dose [37]. Almost all patients $(n=77 ; 98 \%)$ in the $200-\mathrm{mg}$ group experienced an AE. Grade $\geq 3$ AEs were reported in 34 patients (43\%) and 96 patients $(64 \%)$ in the $200 \mathrm{mg}$ and $800 \mathrm{mg}$ groups, respectively; were treatment-related in 25 patients $(32 \%)$ and 65 patients $(43 \%)$, respectively; and led to discontinuation in 11 patients $(14 \%)$ and 22 patients (15\%), respectively [37]. The most commonly reported AEs in the $200 \mathrm{mg}$ and $800 \mathrm{mg}$ groups, respectively, were muscle spasms (54\% and 69\%), alopecia (49\% and 58\%), and dysgeusia (44\% and 60\%).

Overall, data from clinical trials show that vismodegib and sonidegib have similar tolerability profiles and that AEs such as muscle spasms, dysgeusia, and alopecia are class effects. Time to onset was typically within the first 6 months of vismodegib for these common AEs, with median times to onset of 1.9 months for muscle spasms, 3.4 months for alopecia, 1.5 months for dysgeusia, 2.8 months for fatigue, and 6.1 months for weight loss [38]. Median times to onset of common sonidegib AEs were 1.1 months for fatigue, 2.1 months for muscle spasms, and 6.5 months for weight loss [39].

In BOLT, the most common AEs for the $200 \mathrm{mg}$ group at 30 months were muscle spasms (54\%), alopecia (49\%), and dysgeusia (44\%); most AEs were mild, and the most frequent grade $\geq 3$ AEs were elevated creatine kinase (CK) levels (6\%), weight loss (5\%), and muscle spasms (3\%) [40]. It is worth noting that CK monitoring was not part of the ERIVANCE protocol and that the number of patients with CK elevations was not reported in the final analysis [35]. In STEVIE, 44 of 121 patients (36\%) with $>1$ CK measurement who did not experience muscle spasms had elevated $\mathrm{CK}$ levels, and grade $\geq 3$ elevations were reported in 4 patients (3\%) [41]. Among 59 patients in STEVIE with $>1$ CK measurement who did experience muscle spasms, 20 (34\%) had elevated CK levels and 2 (3\%) had grade $\geq 3$ elevations. In MIKIE, CK elevations 
were reported in 11 patients $(10 \%)$ and 15 patients $(14 \%)$ in the 12-week and 24-week regimen groups (grade 3 in $1 \%$ and $4 \%$ of patients, respectively) [36]. Therefore, muscle-related AEs and CK elevation also appear to be a class-related effect of HHIs.

In general, data from pivotal trials suggest that sonidegib has slightly less frequent and less severe AEs compared with vismodegib and that patients treated with sonidegib experience AEs slightly later than with vismodegib (with the exception of fatigue) [39]. Despite the majority of AEs reported in pivotal vismodegib and sonidegib trials being mild (grade 1 or 2 in severity), AEs were a primary reason for early discontinuation and frequently represent a limiting factor in continuous treatment [35]; therefore, dose adjustments or different schemes to avoid discontinuation and increase patient compliance are often required $[42,43]$. Indeed, about 57\% of patients in ERIVANCE discontinued vismodegib, 150 mg, by 39 months due to AEs or physician/patient decision [35], and the corresponding value for sonidegib, $200 \mathrm{mg}$, was about $53 \%$ at 30 months [39].

\section{Managing AEs associated with HHIs in BCC}

The majority of AEs associated with HHIs typically appear after a few weeks from the beginning of treatment; therefore, patient education is vital for better management of these AEs and avoiding treatment discontinuation [44]. Due to the likelihood of AEs resulting in treatment discontinuation, treatment interruptions are frequently used as an approach to manage patient care, especially with AEs of greater severity [14]. Indeed, treatment delay/interruption or dose modification is an important aspect of hedgehog pathway inhibitor treatment for BCC in order for clinicians to best manage their patients' therapeutic course. As noted above, AEs were the main cause of discontinuations from the pivotal vismodegib and sonidegib trials $[35,39]$.

For ERIVANCE, treatment with vismodegib could be interrupted for up to 4 weeks for evaluation of intolerable toxicity or for up to 8 weeks for a planned surgical procedure, and there were no planned dose reductions [34]. Patients with asymptomatic or tolerable severe AEs could continue to receive study drug if the AE was manageable and the patient and investigator agreed that continued treatment was acceptable. Exploratory post hoc analyses were conducted to evaluate the impact of missed vismodegib doses on ORR in ERIVANCE [35]. In the laBCC cohort, ORR was observed in 7 of 12 patients $(58.3 \%)$ with no missed doses and in 31 of 49 patients $(63.3 \%)$ who missed up to $33 \%$ of vismodegib doses (only 2 patients missed $>33 \%$ of doses, both in the laBCC cohort); the corresponding ORRs in the $\mathrm{mBCC}$ cohort were $60.0 \%(6 / 10)$ and $43.5 \%$ (10/23), respectively [35]. In MIKIE, treatment interruptions for up to 2 weeks (up to 4 weeks total within the treatment phase) were permitted to manage toxic events; treatment interruption did not compromise the efficacy of vismodegib [36]. Vismodegib maintained efficacy in a post hoc analysis of data from ERIVANCE and STEVIE using a tumor growth inhibition model to evaluate the effect of 8-week treatment interruptions on efficacy in patients with laBCC and $\mathrm{mBCC}$ [45].

There are no comparable studies that evaluated the impact of dose interruptions of a prespecified length with sonidegib. The BOLT protocol recommended a number of dose modifications and dose delays for suspected treatment-related toxicities; these are summarized in Table 2. For example, in patients with normal CK and grade 1 to 2 muscle-related symptoms, patients continued sonidegib (ie, no dose reduction or delay). In patients with grade $\geq 2$ muscle-related AEs, CK was measured weekly until symptoms resolved to grade $\leq 1$, and for grade $\geq 3$ muscle-related AEs, treatment was delayed. Additionally, in patients with asymptomatic or symptomatic grade 1 to $2 \mathrm{CK}$ elevation, the same dose was continued (CK was monitored weekly until resolution to grade $\leq 1$ in symptomatic $\mathrm{CK}$ elevation). However, in patients with grade 3 to $4 \mathrm{CK}$ elevation, dosing was interrupted and laboratory and CK values were monitored weekly until resolution to grade $\leq 1$; sonidegib treatment resumed at a reduced dose if renal function was not impaired and CK elevation resolved to grade $\leq 1$ within 21 days.

Dose modifications were permitted for patients who were unable to tolerate the protocol-specified dosing schedule or, in the event of toxicities suspected to be related to the study drug, to keep the patient on treatment. A maximum of 2 dose reductions were permitted in patients in the $800 \mathrm{mg}$ group (400 $\mathrm{mg}$ and then 200 $\mathrm{mg}$ ), and a maximum of 1 dose reduction (to placebo) was permitted in patients in the $200 \mathrm{mg}$ group; if there was a need for further dose reductions, the patient was discontinued from study treatment. For patients with any dose interruptions or delays, in those who experienced the same toxicity following re-initiation of treatment, regardless of duration, the second re-initiation of study drug was resumed at a lower dose. Any dose interruption or delay of $>21$ days from the previous dose resulted in discontinuation from study treatment. It is important to note that for those receiving sonidegib, $200 \mathrm{mg}$ (the approved dose for $\mathrm{BCC}$ ), who required a dose reduction, the decreased dose was placebo treatment in BOLT. Dose reductions of sonidegib in clinical practice are therefore not a practical option for patients requiring dose adjustments due to treatment-related AEs. For this reason, treatment interruptions in these patients offer a viable and maintainable option to manage AEs while safeguarding continued course of treatment [46].

Overall, through 42 months of treatment with sonidegib, dose reductions were reported in 13 patients $(17 \%)$ in the $200 \mathrm{mg}$ group and in 55 patients (37\%) in 
Table 2: Recommended dose modifications and dose delays for suspected treatment-related adverse events $^{\mathrm{a}}$

\begin{tabular}{|c|c|}
\hline Worst toxicity; CTCAE grade $^{\mathrm{b}}$ & During a cycle of therapy \\
\hline \multicolumn{2}{|c|}{ General (eg, nausea, dysgeusia, decreased appetite, diarrhea, vomiting, etc) } \\
\hline Grade $1-2$ & Maintain dose level \\
\hline Grade 3 & Omit dose until resolved to grade $\leq 1$, then decrease dose by 1 step \\
\hline Grade 4 & Omit dose and discontinue patient from treatment \\
\hline \multicolumn{2}{|l|}{ Muscle toxicity } \\
\hline $\begin{array}{l}\text { Normal CK with muscle-related symptoms (eg, } \\
\text { pain, spasms, cramps) }\end{array}$ & $\begin{array}{l}\text { Grade } 1-2 \text { symptoms } \\
\text { - Continue sonidegib at same dose; consider symptomatic treatment } \\
\text { for muscle-related toxicity } \\
\text { Grade } 3 \text { symptoms } \\
\text { - Hold dose for } \leq 21 \text { days; measure } \mathrm{CK} \text {; resume sonidegib at a } \\
\text { reduced dose if resolved or improvement to grade } 1 \text { occurs }\end{array}$ \\
\hline Grade 1-2 CK elevation & $\begin{array}{l}\text { Asymptomatic (no new onset or worsening of muscle cramps, myalgia, } \\
\text { or other muscle symptoms) } \\
\text { - Continue sonidegib at same dose and draw blood for } \\
\text { pharmacokinetic analysis } \\
\text { Symptomatic } \\
\text { - Continue same dose; monitor CK at least weekly }\end{array}$ \\
\hline Grade 3-4 CK elevation & $\begin{array}{l}\text { Any occurrence } \\
\text { - Omit sonidegib dose } \\
\text { - Check blood and/or urine myoglobin } \\
\text { - Monitor renal function } \\
\text { - Measure CK at least twice weekly } \\
\text { - Consider electromyography and muscle biopsy } \\
\text { - Consider resuming sonidegib at a reduced dose if renal function is } \\
\text { not impaired and resolution to grade } \leq 1 \text { occurs in }<21 \text { days } \\
\text { - Discontinue patient for renal impairment ( } \mathrm{SCr}>2 \times \mathrm{ULN})\end{array}$ \\
\hline \multicolumn{2}{|l|}{ Cardiac } \\
\hline $\begin{array}{l}\text { Cardiac: prolonged QTc interval grade } \geq 3(\mathrm{QTcF} \\
>500 \mathrm{~ms} \text { or increase of }>60 \mathrm{~ms} \text { from baseline on } \\
\geq 2 \text { separate ECGs) }\end{array}$ & $\begin{array}{l}\text { First occurrence } \\
\text { - Omit dose } \\
\text { - Perform a serum potassium and magnesium analysis; if below } \\
\text { LLN, correct with supplements } \\
\text { - Perform a repeat ECG within } 1 \text { hour of the first QTcF of }>500 \mathrm{~ms} \\
\text { - If QTcF remains }>500 \mathrm{~ms} \text {, repeat ECG as clinically indicated but } \\
\text { at least daily until QTcF returns to }<480 \text { ms } \\
\text { - Once QTcF prolongation has resolved, treatment may be restarted } \\
\text { at a reduced dose level } \\
\text { Second occurrence } \\
\text { - Discontinue patient from treatment }\end{array}$ \\
\hline \multicolumn{2}{|l|}{ General cardiac } \\
\hline Grade $1-2$ & Maintain dose level \\
\hline Grade 3-4 & Omit dose and discontinue treatment \\
\hline \multicolumn{2}{|l|}{ Hepatic: bilirubin } \\
\hline Grade 1 total bili $>$ ULN $<1.5 \times$ ULN & Maintain dose level \\
\hline Grade 2 total bili $1.5-3 \times$ ULN & $\begin{array}{l}\text { Omit dose until resolved to grade } \leq 1 \text {, then: } \\
\text { - If resolved in } \leq 7 \text { days, maintain dose level } \\
\text { - If resolved in }>7 \text { days, decrease dose by } 1 \text { step }\end{array}$ \\
\hline Grade 3 total bili $>3.0-10.0 \times$ ULN & Omit dose until resolved to grade $\leq 1$, then decrease dose by 1 step \\
\hline
\end{tabular}


Omit dose and discontinue treatment

\begin{tabular}{|c|c|}
\hline Hepatic: AST or ALT & \\
\hline Grade $1(>$ ULN $2.5 \times$ ULN) & Maintain dose level \\
\hline Grade $2(>2.5-5.0 \times \mathrm{ULN})$ & Maintain dose level \\
\hline Grade $3(>5.0-20.0 \times \mathrm{ULN})$ & $\begin{array}{l}\text { Omit dose until resolved to grade } \leq 1 \text {, then: } \\
\text { - If resolved in } \leq 7 \text { days, maintain dose level } \\
\text { - If resolved in }>7 \text { days, decrease dose by } 1 \text { step }\end{array}$ \\
\hline Grade $4(>20.0 \times$ ULN $)$ & Omit dose until resolved to grade $\leq 1$, then decrease dose by 1 step \\
\hline AST or ALT $>3.0 \times \mathrm{ULN}$ and total bili $>2.0 \times \mathrm{ULN}$ & Omit dose and discontinue treatment \\
\hline \multicolumn{2}{|l|}{ Renal } \\
\hline Grade $1 \mathrm{SCr}>\mathrm{ULN}<1.5 \times \mathrm{ULN}$ & Maintain dose level \\
\hline Grade $2 \mathrm{SCr} 1.5-3 \times \mathrm{ULN}$ & $\begin{array}{l}\text { Omit dose until resolved to grade } \leq 1 \text {, then: } \\
\text { - If resolved in } \leq 7 \text { days, then maintain dose level } \\
\text { - If resolved in }>7 \text { days, then decrease dose by } 1 \text { step }\end{array}$ \\
\hline Grade $3 \mathrm{SCr}>3.0-6.0 \times \mathrm{ULN}$ & Omit dose until resolved to grade $\leq 1$, then decrease dose by 1 step \\
\hline Grade $4 \mathrm{SCr}>6.0 \times \mathrm{ULN}$ & Omit dose and discontinue treatment \\
\hline
\end{tabular}

Abbreviations: ALT: alanine aminotransferase; AST: aspartate aminotransferase; bili: bilirubin; CK: creatine kinase; CTCAE: Common Terminology Criteria for Adverse Events; ECG: electrocardiogram; LLN: lower limit of normal; SCr: serum creatinine; ULN: upper limit of normal. ${ }^{\mathrm{a}} \mathrm{A}$ maximum of 1 dose reduction (to placebo treatment) was allowed for patients receiving the 200-mg dose, after which the patient would be discontinued from study treatment if there was a need for further dose reduction. ${ }^{b}$ Common Terminology Criteria for Adverse Events (CTCAE Version 4.03) were used.

the $800 \mathrm{mg}$ group; treatment delays were reported in 54 patients $(68 \%)$ and 98 patients $(65 \%)$, respectively [46]. Adverse events accounted for nearly all of the dose reductions and about $60 \%$ and $80 \%$ of the treatment delays in the $200 \mathrm{mg}$ and $800 \mathrm{mg}$ groups, respectively [46]. It is also important to consider the impact of dose reductions and delays on treatment response. A recent subgroup analysis of BOLT indicated that the ORRs and durations of response in patients with dose reductions or delays were similar to those for the overall study group. In the $200 \mathrm{mg}$ group in BOLT, ORRs by central review (laBCC and $\mathrm{mBCC}$ combined) were $48.1 \%$ overall, $46.2 \%$ in patients with $\geq 1$ dose reduction or delay, and $48.5 \%$ in patients without dose reductions or delays [46]. The corresponding ORRs in patients with laBCC were $56.1 \%, 50.0 \%$, and $57.4 \%$, respectively. Results for duration of response and PFS in the $200 \mathrm{mg}$ group were also similar to those in the overall group and in the subgroups of patients with or without dose reductions or delays [46].

\section{CONCLUSIONS}

The HHIs sonidegib and vismodegib are promising treatment options for patients with advanced BCC; however, AEs that occur during treatment with these agents can be difficult for patients to endure and can impact treatment adherence. Therefore, treatment with these agents needs to maintain a balance between disease control and potential adverse reactions. The common AEs observed in vismodegib and sonidegib clinical trials are class-related effects and include muscle spasm, alopecia, dysgeusia, nausea, decreased appetite, and fatigue. Muscle-related effects are also a class-related AE associated with HHIs, and therefore CK levels should be monitored. Additionally, monitoring electrolytes, renal function, and liver function tests is also an important part of treatment care for patients receiving HHIs. Treatment interruptions of vismodegib and sonidegib do not appear to negatively impact the efficacy of these agents and are a practical option for managing AEs in order to maintain a continued course of treatment.

\section{Abbreviations}

AE: adverse event; BCC: basal cell carcinoma; CK: creatine kinase; CR: complete response; DOR: duration of response; EMA: European Medicines Agency; FDA: the Food and Drug Administration; GLI: gliomaassociated oncogene; HHI: hedgehog pathway inhibitors; laBCC: locally advanced basal cell carcinoma; mBCC: metastatic basal cell carcinoma; mRECIST: modified Response Evaluation Criteria in Solid Tumors; ORR: objective response rate; OS: overall survival; PFS: progression-free survival; PR: partial response; RECIST: Response Evaluation Criteria in Solid Tumors; SD: stable disease; SMO: smoothened; STEVIE: SafeTy Events in VIsmodEgib. 


\section{Author contributions}

$\mathrm{JL}, \mathrm{AG}$, and RD had the idea for the article; JL, AG, RD critically revised the work and approved the final manuscript for submission.

\section{ACKNOWLEDGMENTS}

Writing and editorial support for manuscript preparation was provided by Jennifer Meyering, RN, MS, CMPP, of AlphaBioCom, LLC, and funded by Sun Pharmaceutical Industries, Inc., Princeton, NJ, USA.

\section{CONFLICTS OF INTEREST}

JTL receives personal fees from Novartis and Sun Pharmaceutical Industries, Inc.

RD has participated in advisory boards and consulted for Amgen; Bristol-Myers Squibb; Catalym; Merck Sharpe \& Dohme; Novartis Pharmaceutical Corporation; Pierre Fabre; Roche; Sanofi; Second Genome; Sun Pharmaceutical Industries, Inc.; and Takeda. AG has participated in advisory boards for Bristol-Myers Squibb, Pfizer, and Sanofi; received honoraria from Novartis; and received travel support from Astellas; Bristol-Myers Squibb; and Sun Pharmaceutical Industries, Inc.

\section{FUNDING}

This work was supported by Sun Pharmaceutical Industries, Inc.

\section{REFERENCES}

1. Bakshi A, Chaudhary SC, Rana M, Elmets CA, Athar M. Basal cell carcinoma pathogenesis and therapy involving hedgehog signaling and beyond. Mol Carcinog. 2017; 56:2543-57. https://doi.org/10.1002/mc.22690. [PubMed]

2. Marzuka AG, Book SE. Basal cell carcinoma: pathogenesis, epidemiology, clinical features, diagnosis, histopathology, and management. Yale J Biol Med. 2015; 88:167-79. [PubMed]

3. Lear JT, Corner C, Dziewulski P, Fife K, Ross GL, Varma $\mathrm{S}$, Harwood CA. Challenges and new horizons in the management of advanced basal cell carcinoma: a UK perspective. Br J Cancer. 2014; 111:1476-81. https://doi. org/10.1038/bjc.2014.270. [PubMed]

4. Dreier J, Cheng PF, Bogdan Alleman I, Gugger A, Hafner J, Tschopp A, Goldinger SM, Levesque MP, Dummer R. Basal cell carcinomas in a tertiary referral centre: a systematic analysis. Br J Dermatol. 2014; 171:1066-72. https://doi. org/10.1111/bjd.13217. [PubMed]

5. Kim JYS, Kozlow JH, Mittal B, Moyer J, Olencki T, Rodgers P, and Work Group, and Invited Reviewers.
Guidelines of care for the management of basal cell carcinoma. J Am Acad Dermatol. 2018; 78:540-59. https:// doi.org/10.1016/i.jaad.2017.10.006. [PubMed]

6. Basset-Séguin N, Hauschild A, Kunstfeld R, Grob J, Dréno B, Mortier L, Ascierto PA, Licitra L, Dutriaux C, Thomas L, Meyer N, Guillot B, Dummer R, et al. Vismodegib in patients with advanced basal cell carcinoma: Primary analysis of STEVIE, an international, open-label trial. Eur J Cancer. 2017; 86:334-48. https://doi.org/10.1016/i. ejca.2017.08.022. [PubMed]

7. Epstein EH. Basal cell carcinomas: attack of the hedgehog. Nat Rev Cancer. 2008; 8:743-54. https://doi.org/10.1038/ nrc2503. [PubMed]

8. Reifenberger J, Wolter M, Knobbe CB, Köhler B, Schönicke A, Scharwächter C, Kumar K, Blaschke B, Ruzicka T, Reifenberger G. Somatic mutations in the PTCH, SMOH, SUFUH and TP53 genes in sporadic basal cell carcinomas. Br J Dermatol. 2005; 152:43-51. https://doi.org/10.1111/ j.1365-2133.2005.06353.x. [PubMed]

9. Scales SJ, de Sauvage FJ. Mechanisms of Hedgehog pathway activation in cancer and implications for therapy. Trends Pharmacol Sci. 2009; 30:303-12. https://doi. org/10.1016/j.tips.2009.03.007. [PubMed]

10. Odomzo (sonidegib capsules). Full Prescribing Information. Sun Pharmaceutical Industries, Inc.: Cranbury, NJ, USA.

11. European Medicines Agency. Odomzo (sonidegib). Summary of Product Characteristics. 2020.

12. Swissmedic, Authorization Number 65065, 2015.

13. Australian Product Information - Erivedge (vismodegib).

14. Lacouture ME, Dréno B, Ascierto PA, Dummer R, BassetSeguin N, Fife K, Ernst S, Licitra L, Neves RI, Peris K, Puig S, Sokolof J, Sekulic A, et al. Characterization and Management of Hedgehog Pathway Inhibitor-Related Adverse Events in Patients With Advanced Basal Cell Carcinoma. Oncologist. 2016; 21:1218-29. https://doi. org/10.1634/theoncologist.2016-0186. [PubMed]

15. Pak E, Segal RA. Hedgehog Signal Transduction: Key Players, Oncogenic Drivers, and Cancer Therapy. Dev Cell. 2016; 38:333-44. https://doi.org/10.1016/j. devcel.2016.07.026. [PubMed]

16. Rimkus TK, Carpenter RL, Qasem S, Chan M, Lo HW. Targeting the Sonic Hedgehog Signaling Pathway: Review of Smoothened and GLI Inhibitors. Cancers (Basel). 2016; 8:22. https://doi.org/10.3390/cancers8020022. [PubMed]

17. Cross S, Bury J. The hedgehog signalling pathways in human pathology. Curr Diagn Pathol. 2004; 10:157-68.

18. Sekulic A, Mangold AR, Northfelt DW, LoRusso PM. Advanced basal cell carcinoma of the skin: targeting the hedgehog pathway. Curr Opin Oncol. 2013; 25:218-23. https://doi.org/10.1097/CCO.0b013e32835ff438. [PubMed]

19. Amakye D, Jagani Z, Dorsch M. Unraveling the therapeutic potential of the Hedgehog pathway in cancer. Nat Med. 2013; 19:1410-22. https://doi.org/10.1038/nm.3389. [PubMed] 
20. Cortes JE, Gutzmer R, Kieran MW, Solomon JA. Hedgehog signaling inhibitors in solid and hematological cancers. Cancer Treat Rev. 2019; 76:41-50. https://doi.org/10.1016/j. ctrv.2019.04.005. [PubMed]

21. Zito PM, Nassereddin A, Scharf R. Vismodegib. 2021. [PubMed]

22. Erivedge (vismodegib capsules). Full prescribing information. Genentech: San Francisco, CA, USA.

23. Frampton JE, Basset-Séguin N. Vismodegib: A Review in Advanced Basal Cell Carcinoma. Drugs. 2018; 78:1145-56. https://doi.org/10.1007/s40265-018-0948-9. [PubMed]

24. Von Hoff DD, LoRusso PM, Rudin CM, Reddy JC, Yauch RL, Tibes R, Weiss GJ, Borad MJ, Hann CL, Brahmer JR, Mackey HM, Lum BL, Darbonne WC, et al. Inhibition of the hedgehog pathway in advanced basal-cell carcinoma. N Engl J Med. 2009; 361:1164-72. https://doi.org/10.1056/ NEJMoa0905360. [PubMed]

25. Fendrich V, Wiese D, Waldmann J, Lauth M, Heverhagen AE, Rehm J, Bartsch DK. Hedgehog inhibition with the orally bioavailable Smo antagonist LDE225 represses tumor growth and prolongs survival in a transgenic mouse model of islet cell neoplasms. Ann Surg. 2011; 254:818-23. https://doi.org/10.1097/SLA.0b013e318236bc0f. [PubMed]

26. Burness CB. Sonidegib: First Global Approval. Drugs. 2015; 75:1559-66. https://doi.org/10.1007/s40265-0150458-y. [PubMed]

27. Rodon J, Tawbi HA, Thomas AL, Stoller RG, Turtschi CP, Baselga J, Sarantopoulos J, Mahalingam D, Shou Y, Moles MA, Yang L, Granvil C, Hurh E, et al. A phase I, multicenter, open-label, first-in-human, dose-escalation study of the oral smoothened inhibitor Sonidegib (LDE225) in patients with advanced solid tumors. Clin Cancer Res. 2014; 20:1900-09. https://doi.org/10.1158/1078-0432.CCR13-1710. [PubMed]

28. Migden MR, Guminski A, Gutzmer R, Dirix L, Lewis KD, Combemale P, Herd RM, Kudchadkar R, Trefzer U, Gogov S, Pallaud C, Yi T, Mone M, et al. Treatment with two different doses of sonidegib in patients with locally advanced or metastatic basal cell carcinoma (BOLT): a multicentre, randomised, double-blind phase 2 trial. Lancet Oncol. 2015; 16:716-28. https://doi.org/10.1016/S14702045(15)70100-2. [PubMed]

29. Graham RA, Hop CE, Borin MT, Lum BL, Colburn D, Chang I, Shin YG, Malhi V, Low JA, Dresser MJ. Single and multiple dose intravenous and oral pharmacokinetics of the hedgehog pathway inhibitor vismodegib in healthy female subjects. Br J Clin Pharmacol. 2012; 74:78896. https://doi.org/10.1111/j.1365-2125.2012.04281.x. [PubMed]

30. LoRusso PM, Rudin CM, Reddy JC, Tibes R, Weiss GJ, Borad MJ, Hann CL, Brahmer JR, Chang I, Darbonne WC, Graham RA, Zerivitz KL, Low JA, Von Hoff DD. Phase I trial of hedgehog pathway inhibitor vismodegib (GDC0449) in patients with refractory, locally advanced or metastatic solid tumors. Clin Cancer Res. 2011; 17:2502-
11. $\quad$ https://doi.org/10.1158/1078-0432.CCR-10-2745. [PubMed]

31. Graham RA, Lum BL, Cheeti S, Jin JY, Jorga K, Von Hoff DD, Rudin CM, Reddy JC, Low JA, Lorusso PM. Pharmacokinetics of hedgehog pathway inhibitor vismodegib (GDC-0449) in patients with locally advanced or metastatic solid tumors: the role of alpha-1-acid glycoprotein binding. Clin Cancer Res. 2011; 17:251220. $\quad$ https://doi.org/10.1158/1078-0432.CCR-10-2736. [PubMed]

32. European Medicines Agency. Erivedge (vismodegib). Summary of product characteristics. 2016.

33. Lorusso PM, Jimeno A, Dy G, Adjei A, Berlin J, Leichman L, Low JA, Colburn D, Chang I, Cheeti S, Jin JY, Graham RA. Pharmacokinetic dose-scheduling study of hedgehog pathway inhibitor vismodegib (GDC-0449) in patients with locally advanced or metastatic solid tumors. Clin Cancer Res. 2011; 17:5774-82. https://doi.org/10.1158/1078-0432. CCR-11-0972. [PubMed]

34. Sekulic A, Migden MR, Oro AE, Dirix L, Lewis KD, Hainsworth JD, Solomon JA, Yoo S, Arron ST, Friedlander PA, Marmur E, Rudin CM, Chang AL, et al. Efficacy and safety of vismodegib in advanced basal-cell carcinoma. N Engl J Med. 2012; 366:2171-79. https://doi.org/10.1056/ NEJMoa1113713. [PubMed]

35. Sekulic A, Migden MR, Basset-Seguin N, Garbe C, Gesierich A, Lao CD, Miller C, Mortier L, Murrell DF, Hamid O, Quevedo JF, Hou J, McKenna E, et al, and ERIVANCE BCC Investigators. Long-term safety and efficacy of vismodegib in patients with advanced basal cell carcinoma: final update of the pivotal ERIVANCE BCC study. BMC Cancer. 2017; 17:332. https://doi.org/10.1186/ s12885-017-3286-5. [PubMed]

36. Dréno B, Kunstfeld R, Hauschild A, Fosko S, Zloty D, Labeille B, Grob JJ, Puig S, Gilberg F, Bergström D, Page DR, Rogers G, Schadendorf D. Two intermittent vismodegib dosing regimens in patients with multiple basal-cell carcinomas (MIKIE): a randomised, regimencontrolled, double-blind, phase 2 trial. Lancet Oncol. 2017; 18:404-12. https://doi.org/10.1016/S1470-2045(17)300724. [PubMed]

37. Dummer R, Guminksi A, Gutzmer R, Lear JT, Lewis KD, Chang ALS, Combemale P, Dirix L, Kaatz M, Kudchadkar R, Loquai C, Plummer R, Schulze HJ, et al. Long-term efficacy and safety of sonidegib in patients with advanced basal cell carcinoma: 42-month analysis of the phase II randomized, double-blind BOLT study. Br J Dermatol. 2020; 182:1369-78. https://doi.org/10.1111/bjd.18552. [PubMed]

38. Sekulic A, Migden MR, Lewis K, Hainsworth JD, Solomon JA, Yoo S, Arron ST, Friedlander PA, Marmur E, Rudin CM, Chang AL, Dirix L, Hou J, et al, and ERIVANCE BCC investigators. Pivotal ERIVANCE basal cell carcinoma (BCC) study: 12-month update of efficacy and safety of vismodegib in advanced BCC. J Am Acad Dermatol. 2015; 
72:1021-26.e8. https://doi.org/10.1016/j.jaad.2015.03.021. [PubMed]

39. Dummer R, Ascierto PA, Basset-Seguin N, Dréno B, Garbe C, Gutzmer R, Hauschild A, Krattinger R, Lear JT, Malvehy J, Schadendorf D, Grob JJ. Sonidegib and vismodegib in the treatment of patients with locally advanced basal cell carcinoma: a joint expert opinion. J Eur Acad Dermatol Venereol. 2020; 34:1944-56. https://doi.org/10.1111/ jdv.16230. [PubMed]

40. Lear JT, Migden MR, Lewis KD, Chang ALS, Guminski A, Gutzmer R, Dirix L, Combemale P, Stratigos A, Plummer R, Castro H, Yi T, Mone M, et al. Long-term efficacy and safety of sonidegib in patients with locally advanced and metastatic basal cell carcinoma: 30-month analysis of the randomized phase 2 BOLT study. J Eur Acad Dermatol Venereol. 2018; 32:372-81. https://doi.org/10.1111/ jdv.14542. [PubMed]

41. Migden M, Farberg AS, Dummer R, Squittieri N, Hanke CW. A Review of Hedgehog Inhibitors Sonidegib and Vismodegib for Treatment of Advanced Basal Cell Carcinoma. J Drugs Dermatol. 2021; 20:156-65. https:// doi.org/10.36849/JDD.5657. [PubMed]

42. Scalvenzi M, Costa C, Cappello M, Villani A. Reply to Woltsche N. et al. Managing adverse effects by dose reduction during routine treatment of locally advanced basal cell carcinoma with the hedgehog inhibitor vismodegib: a single-centre experience. J Eur Acad Dermatol Venereol. 2019; 33:e145-47. https://doi.org/10.1111/jdv.15469. [PubMed]

43. Ramelyte E, Amann VC, Dummer R. Sonidegib for the treatment of advanced basal cell carcinoma. Expert Opin Pharmacother. 2016; 17:1963-68. https://doi.org/10.1080/ 14656566.2016.1225725. [PubMed]

44. Villani A, Cinelli E, Fabbrocini G, Lallas A, Scalvenzi M. Hedgehog inhibitors in the treatment of advanced basal cell carcinoma: risks and benefits. Expert Opin Drug Saf. 2020; 19:1585-94. https://doi.org/10.1080/14740338.2020.18377 73. [PubMed]

45. Chanu P, Musib L, Wang X, Cheeti S, Girish S, Bruno R, Lu T, Reddy J, Jin JY, Caro I. Vismodegib Efficacy in Advanced Basal Cell Carcinoma Maintained with 8-Week Dose Interruptions: A Model-Based Evaluation. J Invest Dermatol. 2021; 141:930-33. https://doi.org/10.1016/j. jid.2020.07.036. [PubMed]

46. Lewis K, Dummer R, Farberg AS, Guminski A, Squittieri N, Migden M. Effects of Sonidegib Following Dose Reduction and Treatment Interruption in Patients with Advanced Basal Cell Carcinoma During 42-Month BOLT Trial. Dermatol Ther (Heidelb). 2021; 11:2225-34. https://doi.org/10.1007/ s13555-021-00619-4. [PubMed] 